\title{
Labor and Finance as Inevitably \\ Transnational: Globalization \\ Demands a Sophisticated and Transnational Lens
}

\author{
TIMOTHY A. CANOVA* \\ CLAIRE MOORE DICKERSON** \\ KATHERINE V.W. STONE***
}

TABLE OF CONTENTS

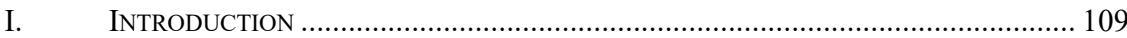

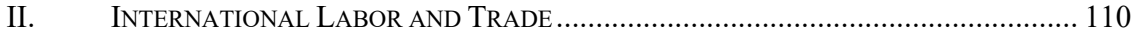

A. Trade as a Threat to Labor Rights ............................................................... 111

B. Two Current Debates........................................................................... 111

1. Labor Rights Versus Labor Standards .......................................... 113

2. Transnational Regulation or Legal Pluralism? ................................... 114

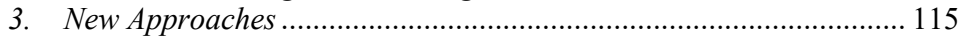

III. INTERNATIONAL MONETARY LAW AND POLICY .................................................. 117

IV. APPLIED INTERNATIONAL AND SOCIOECONOMIC CONCEPTS ............................... 119

* Professor of Law, Chapman University School of Law. Author of Part III.

** Professor of Law and Arthur L. Dickson Scholar, Rutgers Law School, Newark. Author of Parts I \& IV.

*** Professor of Law, Cornell Law School and Anne Evans Estabrook Professor of Dispute Resolution, Cornell School of Industrial and Labor Relations. Author of Part II. 


\section{INTRODUCTION}

To train lawyers to operate effectively in a world of vanishing borders, law schools must include international realities into their domestic law courses. To effect a seamless weave of international and domestic considerations, the perspective must be as broad and inclusive as possible; socioeconomics offers that point of view by inviting the use of richly varied threads.

For years, certain scholars have insisted that law professors should integrate international and domestic law in their teaching. For years, we law professors have resisted, presumably in part because it is daunting to have to learn not only the relevant domestic field, but also the international counterpart-whatever that is. ${ }^{1}$ However, as we prepare lawyers who will work into the middle of the twenty-first century, we no longer have a choice. The world in which our students will practice is complex and will only become more so. Issues of cultural diversity unimagined in the first half of the last century entered legal discourse through critical race theory, and are now exploding into our consciousness through the effects of globalization. We need a template that can encompass not only our narrow, domestic experience, but also the experience of those to whom globalization introduces us.

The dominant paradigm in the legal academy over the past few decades has been law and economics. ${ }^{2}$ Some of the challenges to this school discuss its dependence on a narrow conception of efficiency. For example, perhaps efficiency can mean more than profit maximization; perhaps it can even include distributional effects by espousing an underlying egalitarian value. ${ }^{3}$ That would be a first step, but we need a more radical reshaping of our analytic tools if we are to take into

1. See, e.g., John A. Barrett, Jr., International Legal Education in U.S. Law Schools: Plenty of Offerings, But Too Few Students, 31 InT'L LAW. 845, 856-57 (1997) (recommending the integration of international law in domestic courses); Harold Hongju Koh, The Globalization of Freedom, 26 YALE J. INT'L L. 305, 308 (2001) (observing that as the twentieth century witnessed the move in American law schools from teaching private to public law, the twenty-first century will focus on teaching transnational public law subjects; the issue for the American law schools is how to integrate international and domestic law teaching).

2. See, e.g., Donald C. Langevoort, Theories, Assumptions, and Securities Regulation: Market Efficiency Revisited, 140 U. PA. L. REv. 851, 916 (1992); David Millon, New Game Plan or Business as Usual? A Critique of the Team Production Model of Corporate Law, 86 VA. L. REV. 1001, 1003 (2000).

3. See, e.g., Chris William Sanchirico, Deconstructing the New Efficiency Rationale, 86 CORNELL L. REV. 1003, 1006 n.3, 1069-70 (2001) (asserting that equity, the "equality of economic well-being," is critical to the definition of efficiency); see also Richard S. Markovits, Duncan's Do Nots: Cost-Benefit Analysis and the Determination of Legal Entitlements, 36 STAN. L. REV. 1169, 1176-77, 1194 (1984) (noting that either utilitarianism or egalitarianism can be values underlying an economic efficiency analysis). 
appropriate account the many differences within our globalized arena. ${ }^{4}$ Socioeconomics, a multidisciplinary perspective that welcomes not only economics and psychology, but also anthropology and sociology, can help us broaden our perspective. ${ }^{5}$

Two legal fields that have acutely felt the pressures of globalization are labor and finance law. Parts II and III describe how both of these areas affect and are affected by globalization. These Parts also discuss the contribution of socioeconomics to our understanding of both the impacts of globalization on labor and finance, and potential responses to those impacts. In Part IV, we discuss the importance of consciously and explicitly both recognizing the consequences of globalization, and integrating socioeconomic concepts into our teaching of these areas of the law.

\section{INTERNATIONAL LABOR AND TRADE}

\section{A. Trade as a Threat to Labor Rights}

Globalization refers to the exponential increase in cross-border economic transactions that has occurred over the past twenty-five years. It is the result of a confluence of factors, including trade liberalization by governments, increased foreign direct investment by firms, and changes in transportation and communication technologies that have made it possible for corporations to carry on many aspects of production from anywhere in the world. $^{6}$ Globalization offers many advantages to consumers and producers around the world, but it is not always beneficial for workers. With the increase in global trade and direct foreign investment over the past twenty-five years, the production and

4. An appreciation of cultural differences is at the heart of much legal scholarship today. For two profoundly dissimilar conceptions of cultural differences that nevertheless share a conviction that these differences are important, see generally Douglas Lee Donoho, Autonomy, Self-Governance, and the Margin of Appreciation: Developing a Jurisprudence of Diversity Within Universal Human Rights, 15 EMORY INT'L L. REV. 391 (2001) (discussing conflicts between universal human rights and both national sovereignty and cultural diversity, and suggesting how to avoid the traditional dispute between relativists and universalists through a pragmatic approach based on incremental assertion of jurisdiction by international institutions); Madhavi Sunder, Cultural Dissent, 54 STAN. L. REV. 495 (2001) (asserting that to avoid silencing dissent, law as a normative matter should recognize and protect the diversity within identifiable cultures, both in the United States and abroad).

5. Lynne Dallas, LaW and Public Policy: A Socioeconomic Approach ch. 1 (forthcoming 2004).

6. See generally Katherine Van Wezel Stone, To the Yukon and Beyond: Local Laborers in a Global Labor Market, 3 J. SMALl \& EMERGING BUS. L. 93, 94-95 (1999). 
distribution of goods and services no longer stops at the national border. In addition to an increase in bilateral trade, regional trading blocs and transnational trade regulatory bodies such as the World Trade Organization (WTO $)^{7}$ have proliferated, and trade barriers of all types have decreased.

In this environment of increasingly internationalized production, there is a serious danger that hard-won domestic labor standards and labor rights will be eroded. Free capital mobility and free movement of goods put U.S. workers in competition with low-wage workers around the world. Further, when workers attempt to improve labor standards, they are often confronted with a threat of business relocation to countries with fewer labor protections. ${ }^{8}$ The prospect of capital flight- called "location blackmail" - creates two types of problems for labor. The first problem, known as the race to the bottom, is that firms with significant labor costs will tend to move to lower-cost environments for the labor-intensive aspects of their operations. One consequence is that labor at the bargaining table cannot be aggressive in its demands lest it induce employers to move. The second problem is regulatory competition between states. When firms make credible threats of relocating, it becomes difficult for labor to gain support for legislation granting higher labor standards. Legislators are fearful that they will be blamed if firms in their districts subsequently relocate. Plant closings are poison for political careers. Thus countries have a tendency to lower their worker protective regulations in order to attract or keep business.

Given the damaging potential of unrestricted global trade on labor standards, there is an intense debate about whether, and in what way, trade liberalization should be accompanied by efforts to strengthen labor rights and improve labor standards. ${ }^{9}$ On one side, labor and its supporters in the developed countries (DCs or the North) seek to protect hard-won labor rights by imposing requirements that trade expansion be accompanied by fair labor standards. On the other side, free market advocates oppose any intervention or regulation of the global market. Also, on the other side, some groups in the less developed countries (LDCs or the South) argue that transnational mandatory labor standards are a form of protectionism - that by imposing the high labor standards that currently exist in the developing world, the nations of the developed world prevent jobs from moving to the LDCs. Further, they argue,

7. Final Act Embodying the Results of the Uruguay Round of Multilateral Trade Negotiations, Apr. 15, 1994, 33 I.L.M. 81, available at http://www.wto.org/english/ docs_e/legal_e/ursum_e.htm (last visited Nov. 30, 2003).

8. Stone, suprā note 6, at 97-98 (citing studies).

9. See, e.g., Philip Alston, Labor Rights Provisions in U.S. Trade Law: "Aggressive Unilateralism"?, in HUMAN RIGHTS, LABOR RIGHTS, AND INTERNATIONAL TRADE 71, 71-71, 83-89 (Lance A. Compa \& Stephen F. Diamond eds., 1996). 
mandatory labor standards do not level the playing field, but rather deprive the low-wage countries of their distinct, and often only, comparative advantage.

The issue of protectionism is more complicated than a simple NorthSouth standoff, and it has become apparent that races to the bottom are not simply a North-South problem. Jobs moved from Argentina to Brazil when Brazil changed its tax structure. Jobs are moving from Brazil to Indonesia in pursuit of lower wages. Soon, many jobs will move to China. As races to the bottom become problems for workers in the LDCs, it is becoming evident that a drive for minimal labor standards is not simply labor protectionism by the DCs, but a necessity of workers in both spheres for mutual survival. The spread of globalized production under current rules of trade and institutional arrangements is accompanied by, if not generating, a widening income gap between rich and poor in all countries. Therefore, unions in the DCs increasingly favor some sort of transnational protection for labor rights.

Socioeconomics provides a multifaceted understanding of the threat to labor standards posed by increased trade, portraying the threat not as an inevitability, but as a policy choice. It looks at the cultural and social factors that affect social problems in order to suggest solutions to problems that are often presented as incurable. For example, the socioeconomic approach teaches us to separate the concept of "globalization" from the concept of "free trade." Globalization refers to increased trade, investment, and production across national borders. Over the past several decades, changes in communication and transportation technologies, together with falling tariffs and other trade barriers, have led to more cross-border transactions between private actors. But this increasing globalization of economic life is not the same as "free trade." Free trade is a normative ideal of frictionless markets unfettered by government regulation. Such a regime has never existed, and does not now exist. The issue is not, then, free trade or labor standards - it is what kind of trade regime is most conducive of decent, fair, and equitable labor conditions around the world.

\section{B. Two Current Debates}

At present, there are (at least) two important issues of disagreement among supporters of global labor standards. First, there is the debate between labor standards and labor rights. Second, there is disagreement between those who advocate that global labor standards be established 
and policed by private sector actors, such as progressive pressure groups, consumers, labor unions, and even firms committed to best practices, and those who advocate that global standards be established and policed by transnational governmental-like regulatory agencies with enforcement powers. The former position has been called the legal pluralism approach, ${ }^{10}$ or the Lilliput strategy. ${ }^{11}$ The latter position is the transnational governance approach, which focuses on securing labor provisions in trade treaties and a social clause in the WTO. ${ }^{12}$

\section{Labor Rights Versus Labor Standards}

In 1998, the International Labor Organization (ILO) issued a Declaration on Fundamental Principles and Rights at Work that declared that four labor rights are "fundamental" or "core": (1) the freedom of association, including the recognition of the right to collective bargaining, (2) the elimination of forced labor, (3) the abolition of child labor, and (4) the elimination of employment discrimination. ${ }^{13}$ However, the universal expressions of core labor rights are inherently ambiguous, rendering them difficult to monitor or enforce. Every specific definition of a right - a right to organize, to strike, and so forth - expresses a particular normative vision of the appropriate power relationship between labor and capital. When labor activists use the rhetoric of the right in the general form, they are advocating a particular vision of what the right should mean. While there is nothing wrong with attempting to present one's particular notion of the content of a right in the abstract form, when it is done by advocating labor standards appropriate to the developed world, it is likely to encounter resistance from developing countries. Stated differently, an approach that relies on the four fundamental labor rights may achieve consensus at a high level of abstraction, but if one tries to further particularize and define these rights, the consensus evaporates.

For these reasons, it seems necessary, and more straightforward, to develop an agenda that includes substantive minimal global labor standards. If global labor standards are established not as mathematically

10. See, e.g., H.W. Arthurs, Globalization of the Mind, 12 CAN. J.L. \& SoC'Y 219, 219-221 (1997).

11. Jeremy Brecher et Al., Globalization From Below: The Power of SOlidarity 26-29 (2000).

12. See Virginia A. Leary, "Form Follows Function”: Formulations of International Labor Standards-Treaties, Codes, Soft Law, Trade Agreements, in INTERNATIONAL LABOR STANDARDS 179, 189-203 (Robert J. Flanagan \& William B. Gould IV eds., 2003).

13. InT'L Labour ORG., DeClaration ON Fundamental PRINCIPLES AND RightS AT WORK (1998), available at http://www.ilo.org/public/english/standards/decl/declaration/ text/index.htm (last visited Nov. 30, 2003). 
precise terms but as general benchmarks based on local conditions, it might be possible to arrive at some deeper consensus about what kinds of minimal living wages should be paid, what kinds of safe working conditions are necessary in a humane society, and so forth. For example, in the area of occupational health and safety it should be possible to identify certain minimal safety standards and exposure levels that can be enforced through some kind of international channels. Similarly, it should be possible to define a socially appropriate minimum wage, such as a wage sufficient to feed, house, clothe, and educate oneself and one's family, under existing national economic conditions. These locally tailored benchmarks could then become the minimum standard that a transnational trade organization would enforce. The local benchmark approach advocated here is similar to the concept of the poverty line that was developed in the United States in the 1960s. Such an approach, with its focus in social and cultural as well as economic aspects of human existence and interaction, proposes specific labor standards rather than abstract labor rights. Yet they are locally appropriate standards rather than Western standards set to deprive workers in DCs of jobs.

\section{Transnational Regulation or Legal Pluralism?}

The second issue of current debate concerns who should determine and enforce global labor standards. Should labor standards be established through regulatory bodies, or should they emerge from within civil society? ${ }^{14}$ There have been a number of attempts by regulatory bodies to determine transnational labor standards on a regional scale in recent years. The European Union has used methods of direct regulation and indirect harmonization to achieve convergence in labor standards among member nations. Another method of regulation to affect transnational labor standards is found in the Labor Side agreement to the North American Free Trade Agreement (NAALC), in which a party can bring a complaint against a nation for not enforcing its own labor laws. ${ }^{15}$ These transnational regulatory mechanisms for raising and policing labor standards apply within a specific trading bloc and are embedded within the fabric of treaties that constitutes the rules of the trading bloc more

14. See, e.g., David M. Trubeck et al., Transnationalism in the Regulation of Labor Relations: International Regimes and Transnational Advocacy Networks, 25 LAW \& SOC. INQUIRY 1187, 1188-89 (2000).

15. See Stone, supra note 6, at 111-12. 
generally. Before any of these regulatory mechanisms could be applied globally, there would have to be an international institutional framework governing trade to which they would be attached. Currently, the WTO is the most important global body for regulating trade, but proposals for inserting a social clause in the WTO have been highly controversial and, to date, flatly rejected. The WTO has rebuffed all efforts to address labor standards, taking the position that labor standards are the terrain of the ILO. $^{16}$

In addition to the public regulatory approaches, there are many proposals for mechanisms to raise labor standards through actions by private actors within civil society. ${ }^{17}$ These proposals, in different ways, embody strategies that have been called the "Lilliput strategy" of using small, decentralized actions to tame the global giant. All of them are potentially effective, but they all have limits as well. For example, the ILO's approach of articulating fundamental labor rights and seeking voluntary adherence by means of scrutiny and publicity for countries that do not comply has met with some success, but it is clear that transparency alone does not always change corporate behavior. Similarly, campaigns by the National Labor Committee and other nongovernmental organizations (NGOs) that use publicity to shame corporations with extremely low labor standards have succeeded in bringing about change, but only when they were brought against corporations that produce consumer products that have identifiable name brands. In contrast, it is almost impossible to mount a consumer boycott against a company that produces intermediate goods, such as the dials and gears used inside oil refineries. Also, while NGOs have, at times, succeeded in inducing companies to adopt codes of conduct for their labor conditions, the codes require monitoring. Achieving monitoring and compliance with codes has, to date, proven to be extremely difficult.

Finally, multinational union pressure can be an effective mechanism to raise labor standards, at least where strong unions in more than one country share a common employer. Unions in different countries with a common employer could coordinate contract bargaining goals or contract expiration dates with their counterparts overseas. This is an approach to global labor standards that we can expect to see utilized more frequently in the future, but it would only help employees of multinational firms that had strong unions in several countries. It would

16. Id. at $105-08$.

17. See Arthurs, supra note 10, at 226-43; Michael Posner \& Justine Nolan, Can Codes of Conduct Play a Role in Promoting Workers' Rights?, in INTERNATIONAL LABOR STANDARDS, supra note 12, at 207, 207-26; Trubeck et al., supra note 14, at 1188-92. 
not bring about a harmonization of labor conditions more generally.

Thus, the Lilliput strategy is a series of partial, albeit sometimes effective, techniques to change corporate conduct. Because neither regulatory nor legal pluralist approaches alone can maintain global labor standards, it is necessary to find an approach that bridges the divide between regulation and legal pluralism, between hard law and soft law.

\section{New Approaches}

Socioeconomics insists that private actors and public regulation are inevitably intertwined. Private actor initiatives are the engines that fuel regulatory change, and at the same time, governmental regulations create the field of possibilities upon which private pressures can operate. Therefore, in the area of labor and trade, it is necessary to devise regulatory initiatives that are designed to enable local activists to be effective.

One example of a new approach to labor standards is to link labor rights to intellectual property rights. ${ }^{18}$ In global production, multinational corporations (MNCs) produce using subcontractors all over the world. One of the primary sources of value for producers of consumer commodities lies in the trademark that identifies the product with the multinational firm. The tool of trademark protection enables large retailers and brand-named merchandisers to establish networks of subcontractors who produce their products in the LDCs. For Nike, Banana Republic, Home Depot, and the like, production is diffuse and decentralized, and yet their products command high prices in the market due to the value of their brand name and trademark. Typically, the brand-name business does not own the overseas facility, hire the labor, or supply the raw materials. Rather, the MNCs design the product and then subdivide the production tasks and subcontract each task to firms in the LDCs. The subcontractors often further subcontract to thousands of nameless invisible suppliers. After the composite parts have been assembled, often by another specialty subcontractor, the MNC affixes its brand name to the product and then markets the product to consumers. While all the constituent suppliers are paid all along the commodity chain, the lion's share of the profit accrues to the MNC.

Commodity chain production gives MNCs high profits as a result of the difference between the high consumer price for the finished good

18. Stone, supra note 6, at 129. 
and low costs of production. To reap these profits, the MNCs provide product design, organizational acumen, legal knowledge, and a recognizable trademark. Of these MNC inputs, the trademark is probably the most important source of value. Without trademark protection, other manufacturers could enter the field, copy the product, hire their own subcontractors, and compete away the supra-profits. For example, entire empires have been built upon the Nike swoosh and the image of Mickey Mouse, empires that would quickly collapse without trademark protection.

The MNCs are able to profit from global production arrangements because they can affix a trademark to the product, no matter who produced the good or under what conditions. Yet trademarks are protected by the international trading system. Given the dependency of MNCs on the international trading system for protection of their trademarks, we should consider conditioning MNCs' entitlement to trademark protection to the labor standards under which the goods are produced. That is, we might treat the issue of international regulation of labor standards as an aspect of international protection for intellectual property. For example, we might permit parties to challenge a firm's entitlement to trademark on the basis of the poor labor standards the firm maintains. Or, we might require a party seeking to gain intellectual property rights to demonstrate that it meets some minimum level of labor standards in its facilities. While labor issues may seem irrelevant to intellectual property concerns, property is "bundle of rights," and it is legitimate for social policy to determine what sticks are included in the bundle.

To grant intellectual property protection in today's world is to give the grantee a ticket to produce in the global marketplace. It would not be unreasonable for the state to condition that protection with an obligation to produce under fair conditions in the global labor market. If a trademark signified that a good had been produced under internationally acceptable labor conditions, then consumers could select their goods by seeking those with trademarks. Alternatively, a trademark authority could vary the mark to indicate the degree of compliance, thereby permitting consumers to identify and target those goods produced under substandard conditions. This approach would also enable workers to challenge their labor conditions by contesting the firms' trademark protection for the good so produced. It would give workers and their unions great leverage to bring about change.

This proposal is one example of regulatory change that would empower private actors to bring effective pressure on corporate conduct. However, to achieve trademark conditionality would require a major reorientation in the international intellectual property regime. To bring about such a change will require sustained and coordinated pressure by 
labor groups. The American labor movement learned a century ago that without the clout to take wages out of competition, firms would tend to downgrade rather than upgrade their labor conditions. Labor groups around the world will need to exercise their clout if they want to reform the current shape of global institutions and ensure that globalization means a leveling up rather than a leveling down of working peoples' living standards. Globalization, like a rising tide, can raise all boats or swamp the little ones and sink them to the bottom. It is the role of socioeconomics and law to give social actors the vision and tools they need to stem the tide.

\section{INTERNATIONAL MONETARY LAW AND POLICY}

The field of law and socioeconomics offers a compelling pedagogic vehicle for breathing contemporary relevance into the law school curriculum. This is particularly so in teaching about virtually any aspect of globalization, and certainly international monetary law, a course that stands on its own or as part of other courses in the business law curriculum. ${ }^{19}$ While international monetary law is admittedly a rather specialized area, its presentation through a socioeconomic lens provides ample opportunities for important insights into the contradictions and failings of the dominant law and economics paradigm.

By drawing on a variety of core disciplines, socioeconomics provides an eclectic critique of the orthodox economic paradigm and a far better understanding of economic behavior and market failure than does the simple law and economics "rational person" approach. ${ }^{20}$ Socioeconomics" interdisciplinary approach can also offer compelling reform proposals and alternative paradigms to replace the failing orthodox model. ${ }^{21}$

Socioeconomics dissects the assumptions of the orthodox paradigm. For neoclassical economics, the legitimizing assumption in international trade theory is David Ricardo's "law of comparative advantage," a justification for free trade policies that seeks to explain how trade should maximize each nation's output. ${ }^{22}$ According to Ricardian theory, each

19. For instance, international monetary law should increasingly be seen as a necessary component of any course in international trade law or international business transactions.

20. Robert Ashford, Socio-Economics: What Is Its Place in Law Practice?, 1997 WIS. L. REV. 611, 612.

21. Socioeconomics draws upon such core disciplines as history, psychology, political science, anthropology, economics, and sociology. Id.

22. Michael H. Davis \& Dana Neacsu, Legitimacy, Globally: The Incoherence of Free Trade Practice, Global Economics and Their Governing Principles of Political 
country should produce those goods for which it has a comparative advantage, and then trade such goods for others produced more efficiently elsewhere. ${ }^{23}$ In this way, labor specialization and trade liberalization are supposed to allow each nation to maximize its output and aggregate income. ${ }^{24}$

Socioeconomics dissects the Ricardian model from a variety of vantage points. It argues that even if a comparative advantage results in increasing output, the gains in output and income are aggregate gains. However, when disaggregated, trade liberalization necessarily results in winners and losers within each country, thereby creating new and exacerbating existing political and social tensions. ${ }^{25}$ From a utilitarian perspective, losers should be compensated and retrained from declining to rising industries, an approach that requires the same kind of interventionist government policies that are often criticized by law and economics as antimarket. ${ }^{26}$ As a practical matter, without such redistributionist and industrial policies, the costs of trade liberalization are not shared equitably, and as a result, there is often fierce political opposition to trade liberalization.

In addition to inequities within individual countries, trade rarely balances out between countries in the real world. In a regime of freely floating

Economy, 69 UMKC L. REV. 733, 751, 755 (2001) (arguing that in international trade law "legitimacy seems to derive from the tacit agreement, underlying virtually all, if not all, of the WTO and GATT rules, that the law of comparative advantage is valid").

23. DAVID RicARDo, ON THE PRINCIPLES OF POLITICAL ECONOMY AND TAXATION 132-34 (3d ed. 1821), reprinted in 1 THE WORKS AND CORRESPONDENCE OF DAVID RICARDO 1, 132-34 (Piero Sraffa ed., 1953).

24. William J. Baumol \& Alan S. Blinder, Economics: Principles and Policy 801 (7th ed. 1998).

25. The great British economist John Maynard Keynes, an opponent of the laissez faire do-nothing policy of his day (and therefore one of the grandparents of socioeconomics), once wrote: "In the long run we are all dead." JOHN MAYNARD KEYNES, MONETARY REFORM 88 (1924). Today, we should entertain a corollary to Keynes's dictum: "In the aggregate we are alright. But in the disaggregate, many of us are not." While the orthodox free-market model may restore a country's trade balance (in the aggregate) and may permit a resumption of income and economic growth (in the aggregate), the distribution of the growth is by necessity, if not design, a top-heavy one in which the elites reap the lion's share of the pie.

26. For instance, the Reagan administration displayed such a law and economics animus for retraining workers displaced by foreign imports when it reduced federal spending on trade adjustment assistance. Timothy A. Canova, Monologue or Dialogue in Management Decisions: A Comparison of Mandatory Bargaining Duties in the United States and Sweden, 12 COMP. LAB. L.J. 257, 263 (1991); see also MiLTON FrIEDMAN \& Rose Friedman, Free to Choose: A Personal Statement (1980) (arguing against public education as contrary to market preferences and in favor of the privatization of education through vouchers); Alan O. Sykes, Protectionism as a "Safeguard": A Positive Analysis of the GATT "Escape Clause" with Normative Speculations, 58 U. CHI. L. REV. 255, 269-74 (1991) (arguing against trade adjustment assistance for displaced workers). 
exchange rates, fluctuations in currency values provide the adjustment mechanism to bring trade and payments back into balance. A country with a trade and current account deficit could adjust to balance by depreciating the value of its currency, which should boost its exports and make imports more expensive. ${ }^{27}$ But in reality, chronic trade deficit countries have generally not adjusted well through the mechanism of flexible exchange rates. ${ }^{28}$

Among the chief reasons for the failure in exchange rate adjustment has been the incentive for deficit countries to keep their currencies strong (that is, overvalued) to attract scarce private foreign portfolio investment. But as experience shows, the overvalued currency only exacerbates the trade deficit while necessitating further inflows of foreign capital. ${ }^{29}$ Eventually, the house of cards collapses and foreign investors run to the door, all in a panic to sell at once. The deficit country's currency finally falls with a violence that sharply erodes domestic savings, ushers in inflation, and leads all too often to International Monetary Fund (IMF) emergency assistance that is tied to an agenda of economic austerity. ${ }^{30}$

The World Bank's own statistics show that orthodox economic

27. BAUMOL \& BLINDER, supra note 24, at 832-33 (noting that, likewise, a country with a trade and current account surplus would require an appreciation in its currency to return to trade balance).

28. A number of commentators have recognized the virtues of a system of semifixed exchange rates that would provide for flexibility within a narrow range and orderly mechanisms for adjustment of such ranges. For instance, the 1994 Bretton Woods Commission, chaired by former Federal Reserve Chairman Paul Volcker, criticized liberalized exchange rates and advocated a return to a regime of semifixed exchange rates. BRETTON WOODS COMM'N, BRETTON WOODS: LOOKING TO THE FUTURE A-4 (1994); see also Paul Volcker, Toward Monetary Stability, WALl ST. J., Jan. 24, 1996, at A12.

29. For a description of this cycle of dependence on hot money inflows, see Timothy A. Canova, Banking and Financial Reform at the Crossroads of the Neoliberal Contagion, 14 AM. U. INT'L L. REV. 1571, 1604 (1999).

30. In exchange for IMF and World Bank assistance, deficit countries are expected to adopt and implement a range of deflationary monetary and fiscal policies and other reforms, in the past known as a structural adjustment program, and often documented through so-called letters of intent. The process is often referred to as one of "loan conditionality" because the IMF loans are conditioned upon implementation of the policy reforms. Typically, a deficit country must agree to a strict diet of "fiscal discipline" that will entail severe cuts in government spending, increases in taxes, and sometimes user fees for health care and education. Richard Gerster, The IMF and Basic Needs Conditionality," 16 J. WORLD TRADE L. 497, 497-98 (1982); see also WARREN NyAmugasira \& Rick Rowden, New Strategies, Old LoAn Conditions 32 (2002) (criticizing new IMF and World Bank poverty reduction strategies), available at http://ibp. forumone.com/resources/library/title.flml?letter=N. 
policies have had little impact in improving people's lives around the world. $^{31}$ Throughout the world, the widening gulf between the super-rich, the middle and working classes, and the poor now poses a clear and present danger to our national and global security interests. ${ }^{32}$

While law and socioeconomics recognizes that the Ricardian model is actually premised on the immobility of capital, ${ }^{33}$ too many mainstream texts for courses in international business law still completely fail to discuss such limitations of the Ricardian model or the increasing significance of cross-border investment flows, including "hot money" portfolio capital flows. ${ }^{34}$ New international trade theory has improved

31. Of the 4.7 billion people who live in the 100 countries that are World Bank and IMF clients, 2.8 billion live on less than $\$ 2$ a day and 1.2 billion live on less than $\$ 1$ a day; as a result of such poverty, 33,000 children die every day and more than 100 million children, most of them girls, are not in school. These statistics are from the World Bank's official web site. See The World Bank Group, What Is the World Bank, at http://web.worldbank.org (last visited Oct. 11, 2003). The pain of sudden ruin and mass unemployment has contributed to dramatic escalations in street crime, ethnic violence, and political instability on a global scale. Timothy A. Canova, Global Finance and the International Monetary Fund's Neoliberal Agenda: The Threat to the Employment, Ethnic Identity, and Cultural Pluralism of Latina/o Communities, 33 U.C. DAVIS L. REV. 1547, 1559-66 (2000).

32. Richard C. Bell \& Michael Renner, A Global Marshall Plan to Fight Terrorism, COMMON DREAMS NEwS CENTER, at http://www.commondreams.org/views01/1006-06.htm (Oct. 6, 2001) (noting that, in outlining his plan on June 5, 1947, General George C. Marshall said that there could be "no political stability and no assured peace" without economic security, and that U.S. policy should be "directed not against any country or doctrine but against hunger, poverty, desperation, and chaos").

33. DALlas, supra note 5, at ch. 11. Ricardo apparently believed that capital immobility was a positive characteristic.

For Ricardo it is the force of community that keeps capital at home even in the face of higher profits abroad. Furthermore he affirms that he would be sorry to see these feelings of community weakened. Perhaps he already suspected that they would be weakened by the individualistic postulates of classical economics and its faith in the invisible hand's ability to transform private vice into public virtue.

Id.; see also Sara Dillon, Trade and the Environment: A Challenge to the GATT/WTO Principle of "Ever-Freer Trade," 11 ST. JOHN's J. LEGAL COMMENT. 351, 380-81 (1996) (arguing that serious flaws in the Ricardian doctrine of comparative advantage should compel policymakers to develop a more cogent justification for free trade policies).

34. An example of this market myopia is in RALPH H. FOLSOM ET AL., INTERNATIONAL BUSINESS TRANSACTIONS (6th ed. 2003), a casebook which, incredibly, makes no mention of the vast expansion in cross-border portfolio capital flows or any of the policy debates about capital liberalization. But other texts have appreciated the limitations of the Ricardian model. See, e.g., PAUL B. STEPHAN III ET AL., INTERNATIONAL BUSINESS AND ECONOMICS: LAW AND POLICY 223 (1993) (stating that the Hume-Smith-Ricardo classical model "ignored the effect of capital flows"). After reporting on the enormous increase in international capital movements since the end of World War II, the authors conclude how easy it is "to see how capital flows affect national accounts and, therefore, how incomplete the Hume-Smith-Ricardo analysis has become." Id. at 224; cf. Charles Schumer \& Paul Craig Roberts, Second Thoughts on Free Trade, N.Y. TIMES, Jan. 6, 2004, at A23 (arguing that Ricardo assumed the immobility of factors of production). 
upon the Ricardian model in its ability to take capital flows into account, ${ }^{35}$ and some leading modern trade theorists have reluctantly acknowledged the dangers posed by today's volatile maze of capital flows. ${ }^{36}$ Unfortunately, that has not stopped many in the legal academy from retelling the fairy tale of Ricardian comparative advantage as an immutable fact that always justifies free trade in goods and services, as well as free capital flows. ${ }^{37}$

By the mid-1990s, there was about $\$ 315$ billion in annual global foreign direct investment, mostly investment in fixed plant and equipment by multinational corporations, and over $\$ 1.2$ trillion a day in foreign exchange transactions, much of which goes for portfolio investment (for example, the purchase of foreign stocks and bonds). ${ }^{38}$ But because portfolio

35. Paul Krugman \& Maurice Obstfedl, International Economic Relations (1997). Bertil Ohlin is among those credited with relaxing the assumption that the factors of production are immobile, a necessary step on the way to the new theory of international trade as articulated by economists such as Paul Krugman, Avinash Dixit, and Albert S. Kyle. AN ENCYClOPEDIA OF KEYNESIAN ECONOMICS 488 (Thomas Cate ed., 1997); see also Robin Hahnel, PaniC Rules: Everything You NeEd to Know ABOUT THE GLOBAL ECONOMY 17-20 (1999) (providing a critique of the Hecksher-Ohlin theory); Davis \& Neacsu, supra note 22, at 755 (discussing the Heckscher-Ohlin theorem, also known as the "factor endowment approach," which explains that "countries with abundant capital will engage in capital-intensive industries and labor-rich countries will engage in labor-intensive activities").

With regard to the interwar transfer problem, Ohlin argued that Germany should use monetary and fiscal austerity to reduce its level of income and thereby create a trade surplus out of which reparations could be paid. Id. This can be seen as the intellectual precursor to the IMF's structural adjustment model, by which developing countries pay interest on their international debt obligations out of trade surpluses created in conditions of economic austerity.

36. Paul Krugman, An Open Letter to Prime Minister Mahathir (Sept. 1, 1998) (arguing in favor of capital and exchange controls to promote "a recovery of the real economy"), available at http://web.mit.edu/krugman/www/mahathir.html; Paul Krugman, Curfews on Capital Flight: What Are the Options? (Oct. 12, 1998) (discussing "cooling-off" periods for capital flight), available at http://web.mit.edu/krugman/www/curfews.html (last visited Jan. 14, 2004); Paul Krugman, Saving Asia: It's Time to Get Radical, ForTUNE, Sept. 7, 1998, at 75, 79 (arguing for temporary currency controls as part of the solution to the "Great Asian [Economic] Slump").

37. FOLSOM ET AL., supra note 34, at 2-11 (including a simplistic account of the free trade myth thinly disguised with names such as Westia, Tropica, and Egalia as covers for developed market economies, developing nations, and nonmarket economies); FeD. Reserve BANK OF N.Y., The StORY OF Foreign Trade AND Exchange (1998) (presenting a simplified comic book version of the free trade fairy tale).

38. DALlAS, supra note 5, at ch. 11. Professor Dallas also points out that the total volume of international trade in goods was about $\$ 5$ trillion a year by the mid-1990s, about as much value as changes hands in the foreign exchange markets each week. Id. FDI flows peaked in 2000 at over $\$ 1$ trillion a year, still well below the levels of crossborder foreign exchange and portfolio capital flows. U.N. CONFERENCE ON TRADE AND 
investment is highly liquid, it can also be highly unstable. Economists sometimes refer to portfolio investment as the "hot money problem" to describe how quickly market sentiment can irrationally turn from exuberance to fear, and how devastating it can be when investors all try to liquidate their investments and sell at the same time. ${ }^{39}$

Unquestioning adherence to Ricardian theory by today's neoclassical orthodoxy often results in flawed and dangerous policies. It permits policymakers to simplistically blame the victims - often the deficit countries-while absolving surplus countries from any responsibility. This adherence to outdated theories and assumptions has become an ideological straightjacket, confining the policy and imagination of monetary authorities around the world, particularly at the IMF, which has become one of the bunkers of orthodox economic thinking in monetary affairs.

However, socioeconomics provides compelling explanations for the failings of today's corporate globalization model. It borrows from heterodox economics and the field of psychology to explain the mass psychosis of a currency contagion that has ravaged so many countries around the world in the past decade. ${ }^{40}$ Analysis of narrative discourse and mass communications studies help explain how elite opinion and the mass media keeps the dominant model entrenched through both elite and popular discourse. ${ }^{41}$ Political science offers such constructs as captured agencies, iron triangles, and revolving doors to explain the mechanisms by which private power has corrupted the mission of public regulators to provide transparent market rules and stable capital markets. ${ }^{42}$

DEVELOPMENT, ESTIMATED FDI FLOWS IN 2001 AND THE IMPACT OF THE EVENTS IN THE United States, Note By the SECRETARIAT (2001) (estimating a forty percent decline in FDI flows, from $\$ 1.2$ trillion to $\$ 760$ million, in 2001 as a result of the September 11th aftermath), available at $\mathrm{http}: / / \mathrm{www}$.unctad.org/en/docs/poitem49.en.pdf.

39. Joseph E. Stiglitz, Globalization AND ITs Discontents 65-66 (2002) (referring to "hot money" as "short-term loans and contracts that are usually no more than bets on exchange rate movements"); Sandra Polaski, Understanding the Peso Crisis-Was It Related to NAFTA?, in JOHN J. AUdLEY ET AL., NAFTA's PROMISE AND REALITY: LESSONS FROM MEXICO FOR THE HEMISPHERE 11, 18-19 (2003) (referring to portfolio capital as "mobile" or "footloose" investment in government bonds and corporate stocks and bonds).

40. Psychology helps to deconstruct the orthodox economic assumptions of autonomy, rationality, and efficiency and provide more realistic explanations for economic behavior. See generally DonAld N. MCCloskey, KNOWLEdGE AND PERSUASION IN ECONOMICS (1994).

41. Canova, supra note 29, at 1586-95 (discussing how dominant neoliberal discourses are used to justify NAFTA's financial liberalization provisions).

42. The political science critique also borrows from legal realists, institutionalists, and the public choice theorists. JoHn KenNETH Galbraith, ECONOMICS AND THE PubliC Purpose 142-44 (1973); TheOdore J. Lowi, The END of Liberalism 60-61, 82-84 (2d ed. 1979) (characterizing the agency capture problem as inherent in a system of interest group pluralism); John Shepard Wiley, Jr., A Capture Theory of Antitrust Federalism, 99 
Socioeconomics also employ legal doctrines, such as unconscionability doctrine from contract law, to impeach the sanctity of international trade agreements between formally rational and autonomous nation states by pointing to the great disparities in bargaining power that actually exist between such parties. ${ }^{43}$ Socioeconomics easily draws on history to explain the inevitable folly of fully liberalized capital markets. ${ }^{44}$ And nothing short of anthropological inquiry can possibly explain the mystique, secrecy, cultural traditions, and learned patterns of thought and behavior that have both empowered and constrained the flailing leaders of the financial orthodoxy. ${ }^{45}$

Socioeconomics also looks to history and heterodox economics to suggest alternative directions for reform, including a revitalized regulatory model consisting of controls on hot money capital flows. ${ }^{46}$ While some neoclassical advocates argue reflexively against capital controls, even

HARV. L. REV. 713, 715 (1986) (arguing that courts came to regard regulation "as economically inefficient and as the product not of broad political consensus but of the capture of lawmaking bodies by producer groups seeking benefit at the expense of others"). The power of entrenched interests became apparent when Joseph Stiglitz was forced to resign as chief economist of the World Bank for his repeated criticism of IMF policy. Stiglitz was awarded the Nobel Prize in Economics only a year later. Canova, supra note 31, at 1573-74; see also STIGLITZ, supra note 39, at $\mathrm{x}-\mathrm{xvi}$ (describing his frustration with IMF policies that were formulated on the basis of ideology "that seemed to be thinly veiling special interests").

43. Davis \& Neacsu, supra note 22, at 747 (arguing that uncontested assumptions of the law of comparative advantage foreclose debate on questions dealing with the autonomy, competence, and relative bargaining power of Third World countries, and therefore on the enforceability of international agreements).

44. John Eatwell \& Lance Taylor, Global Finance at Risk 31-34 (2000) (recounting nineteenth and twentieth century history of destabilizing capital flows); Charles P. Kindleberger, The World in DePression 1929-1939, at 146-70 (recounting the 1931 currency contagion, cross-border transmission of financial crisis throughout Europe and to the United States).

45. For instance, investigative journalistic accounts have deepened our understanding of the Federal Reserve and foreign central banks more than any mainstream economic analyses. See generally WiLliam GreIder, SeCrets of the TEMPle 48-55 (1987) (analyzing U.S. monetary history and the Federal Reserve System); DAVID MARSH, THE MOST POWERFUL BANK 45-48 (1992) (providing an analysis of the German Bundesbank); Steven Solomon, The Confidence Game 26-37, 63-79, 110-22 (1995) (providing an analysis of central banking and globalization of finance).

46. Article VI of the IMF Articles of Agreement permits member nations to implement controls on capital flows. Such controls could take the form of regulatory or reserve requirements on inflows or outflows, or a turnover tax on foreign exchange transactions (the so-called Tobin tax). Canova, supra note 29, at 1610, 1622-33 (including discussion of the Tobin tax proposal by the late James Tobin, another Nobel laureate, to tax foreign exchange transactions "to throw sand in the gears of the speculators" while raising hundreds of billions of dollars to fund a global Marshall Plan). 
asserting quite laughably that there has never been a single example of effective capital controls, ${ }^{47}$ the historical record is quite clear that such restrictions were extremely effective in shielding Western Europe from speculative damage during post-war reconstruction. ${ }^{48}$ In more recent years, Chile weathered the "tequila effect" of the currency contagion by the use of prudential restrictions on capital flows ${ }^{49}$ and even the IMF felt forced to concede that Malaysia's use of capital controls (and more intrusive exchange controls on current transactions) were effective as well. ${ }^{50}$

47. Letter from Michael Gordon to Michael Norwood (Jan. 22, 2003) (on file with author). Gordon's invective against critics of free trade policies is not merely "trivial name calling" but an example of how dominant ideologies (and their proponents) attempt to devalue their opponents and exclude them from public discourse. Davis \& Neacsu, supra note 22, at 734-35 (arguing that "one of the hegemonic and legitimating features of globalization is the exclusion of parts of the debate as unworthy, in fact foreclosing what might be the most meaningful parts of the debate as meaningless").

48. For most Western European countries, capital controls remained in place throughout most of the 1950s, and for some countries, until the early 1990s. FRED L. BLOCK, THE ORIGINS OF INTERNATIONAL ECONOMIC DISORDER 109-37 (1977) (providing a history of post-war Western European currency controls; throughout the Marshall Plan period no major European currency was convertible); MARGARET GARRITSEN DE VRIES, BAlANCE OF PAYMENTS ADJustment, 1945 to 1986: THE IMF EXPERIENCE 30-32 (1987); Duncan E. Williams, Policy Perspectives on the Use of Capital Controls in Emerging Market Nations: Lessons from the Asian Financial Crisis and a Look at the International Legal Regime, 70 ForDHAM L. REV. 561, 562-63 (2001).

49. Canova, supra note 31, at 1621. Likewise, throughout 2003, Thailand imposed capital controls to keep its financial markets from overheating while its economy was surging. Wayne Arnold, Thailand Sets Path to a Better Economy, N.Y. TIMES, Oct. 24, 2003, at W1 (reporting Thai capital controls that restrict nonresidents from holding more than 300 million baht ( $\$ 7.5$ million) and require them to keep their funds in a Thai bank for at least six months); Shawn W. Crispin, Thai Boom Is Raising Concerns, WaLl ST. J., Nov. 28, 2003, at A6 (reporting a "mild form of capital controls barring financial concerns in Thailand from borrowing baht from foreigners except to finance a specific business transaction").

50. Michael M. Phillips, IMF Concedes that Malaysia's Controls over Capital Produced Positive Results, WALL ST. J., Sept. 9, 1999, at A21. One noteworthy critic of capital restrictions, Michael Gordon, was completely oblivious to the IMF's conclusion about the success of Malaysia's program of capital controls, as well as the record of capital controls in Chile in the 1990s, throughout Western Europe from the 1950s to the 1990 s, and throughout East Asia today, or even the very public debates within both the IMF and World Bank about the pace and sequencing of capital account liberalization. Letter from Michael Gordon, supra note 47. Gordon, no doubt, would have also missed the news that China's capital controls were proving so successful at keeping its currency undervalued and its trade surplus with the United States so large that the Bush administration made it into a major diplomatic issue. Joseph Kahn, China Resisting Pressure from U.S. Treasury Chief to Ease Its Currency Policy, N.Y. TIMES, Sept. 3, 2003, at A8 (reporting that U.S. Treasury Secretary, under heavy political pressure at home, was calling on Chinese officials to relax their "capital controls that restrict the amount of foreign currency Chinese companies and individuals can take out of the country"); $c f$. Jagdish Bhagwati, The Capital Myth: The Difference Between Trade in Widgets and Dollars, FOREIGN AFF., May/June 1998, at 7, 10 (pointing out that China and Japan have registered remarkable growth rates, and Western Europe returned to prosperity, without capital account convertibility). 
A more honest and intelligent approach to capital account liberalization would view the issue in terms of pace and sequencing, particularly because many developing countries may not be prepared for full liberalization of hot-money portfolio capital flows until they have developed their institutional and legal infrastructures. ${ }^{51}$ In this way, the discussions about capital account liberalization can be tied to other "rule of law" reforms in developing countries that focus on creating stable political and legal institutions. ${ }^{52}$

Unfortunately, academic and public debates about globalization often degenerate into all-or-nothing dead ends that offer little more than false dichotomies. ${ }^{53}$ For instance, many commentators are either completely for free trade, NAFTA, the WTO, the IMF, and unfettered mobility of any and all kinds of capital, or completely against them, with few articulating reform positions. Likewise with discussions about rule of law reforms. It is tempting to dismiss rule of law reforms that obscure the need for other, external reforms ${ }^{54}$ or that seek to impose foreign values or limit the capabilities of developing countries to choose their own models of development. ${ }^{55}$ But at its best, rule of law reforms

51. R. Barry Johnston, Sequencing Capital Account Liberalization, FIN. \& DEV., Dec. 1998, at 20 (arguing that an appropriate regulatory framework should precede financial sector liberalization). Stiglitz was particularly critical of the IMF's failures in the sequencing and pacing of its liberalization program imposed prematurely on countries with weak institutions. STIGLITZ, supra note 39, at 73-74.

In early 2003, the IMF's chief economist, Kenneth Rogoff, coauthored a "sobering" report concluding that there was no clear proof that financial globalization helps poor countries and finding that financial integration may increase the risk of financial crisis in the developing world. The report was not able to come up with a "clear roadmap" for how countries can open themselves up to foreign investment, including highly liquid investments in portfolio capital. ESWAR PRASAD ET AL., INT'L MONETARY Fund, EFFECTS of Financial Globalization on Developing Countries: Some EMPIRICAL EVIDENCE 57, 58 (2003), available at http://www.imf.org/external/np/res/docs/2003/031703.pdf.

52. Andre Newburg, The Changing Roles of the Bretton Woods Institutions: Evolving Concepts of Conditionality, in INTERNATIONAL MONETARY LAW: ISSUES FOR THE NEW MILLENNIUM 81, 87 (Mario Giovanoli ed., 2000) (describing the new conditionality in the 1990s as focusing on governance concerns and stable political and legal institutions).

53. Timothy A. Canova, The Disorders of Unrestricted Capital Mobility and the Limits of the Orthodox Imagination, 9 MinN. J. Global TRADE 219, 224 (2000) (book review) (describing the false dichotomies of globalization debates).

54. See Canova, supra note 29, at 1593-94 (arguing that legal reform narratives obscure the destructive nature of the IMF's structural adjustment policies).

55. For instance, the IMF has promoted central bank autonomy as part of its new conditionality of good governance legal reforms. For instance, see KEMAL DERVIS \& Surevyya Serdengecti, Memorandum on ECONOMiC Policies (2001) (stating Turkey's commitment to amend its central bank law "to give full operational independence to the central bank in pursuing its primary mandate of maintaining price stability"), available 
provide baseline rules for private markets to flourish, and therefore would complement necessary external reforms (such as relaxing the IMF's austerity conditions and increasing levels of foreign aid). ${ }^{56}$

Socioeconomics supports a broad, reformist perspective that includes public investment in physical infrastructure (such as transportation and communication systems), social infrastructure (such as education and training), and legal infrastructure. ${ }^{57}$ Developing legal infrastructure-the very ground rules for private markets - is quintessentially socioeconomic in approach and facilitates economic development by protecting private contracts and property rights. ${ }^{58}$

Legal reform efforts have also evolved from crude proposals that would simply impose U.S. legal codes on developing countries to multilateral projects that reflect the variety of local conditions, such as the Organization of American State's (OAS) Model Law of Secure Transactions recently unveiled by the World Bank. ${ }^{59}$ Such reform efforts would help countries develop their private capital markets and grow their economies, thereby increasing the tax base and supporting

at http://www.imf.org/external/NP/LOI/2001/tur/02/INDEX.HTM (May 3, 2001). But the agenda of central bank autonomy is highly contestable. See Timothy A. Canova, Financial Liberalization, International Monetary Dis/Order, and the Neoliberal State, 15 AM. U. INT'L L. REV. 1279, 1294-1302 (2000) (arguing that central bank autonomy is based on flawed history and limited economic assumptions).

56. This Author wishes to acknowledge his own previous errors in prematurely rejecting efforts to create the legal infrastructure necessary to develop private enterprise and capital markets. Cf. Canova, supra note 29, at 1591. My rethinking of these issues has been heavily influenced by the works of the Peruvian economist Hernando de Soto, numerous discussions and friendly debates with Frank Gill, Ted Parnall, Alan Swan, and Keith Rosen, and the good faith and exemplary good works of Boris Kosolchyk and his National Law Center for Inter-American Free Trade. The Author is also indebted to David Gantz, Sandy Gaines, and Raj Bhala for demonstrating that support for freer trade can be consistent with responsible global citizenship.

57. Many developing countries have difficulty investing sufficiently in their own infrastructure, often because of the fiscal austerity imposed as conditions for IMF financial assistance. Reform of the adjustment model is therefore necessary to permit countries to invest in developing their own resources.

58. Hernando de Soto, The Mystery of CAPITAL 49-51 (2000) [hereinafter DE SOTO, THE MYSTERY] (arguing that legal protections for private property and contract are two often overlooked prerequisites for capital and market economy development); Hernando De Soto, The Other PATH: The ECONOMic ANSWER to Terrorism 177-82, 250-51 (1989) [hereinafter DE Soto, THE OTHER PATH]; World BANK, DoING Business IN 2004: UNDERSTANDING REGULATION ix-x (2004) (advocating regulatory reforms and comparing 130 countries on the basis of quantitative indicators of business regulations of property relations, contract rights, starting and closing a business, and credit and labor markets).

59. Boris Kozolchyk \& Dale Beck Furnish, The OAS Model Law on Secured Transactions: A Comparative Analysis, GlOBAL FORUM ON INSOLVENCY RISK MANAGEMENT (World Bank, forthcoming 2004) (analyzing the importance of modern secured transactions law, contrasting Article 9 of the U.S. Uniform Commercial Code with the Mexican Reform Laws of May 2000 and June 2003, and the Model InterAmerican Law on Secured Transactions of the Organization of American States). 
public investment in infrastructure. ${ }^{60}$

Of course, many countries may need help in achieving and maintaining adequate levels of public investment. Foreign aid, including the recycling of surpluses through public sector capital transfers, is another policy that finds support in the socioeconomic approach. Such foreign assistance has strong precedent in the Marshall Plan, ${ }^{61}$ a compelling historical success that is raised time and again as a model for achieving important economic and strategic objectives around the world. ${ }^{62}$

Socioeconomics does not seek to outlaw or banish private market mechanisms, but merely to provide rules and sensible limits on market activity. ${ }^{63}$ Such a regulated global investment environment would benefit not just poor and developing countries, but also wealthy creditor and donor nations that have been hit hard by slow growth, global overcapacity, private sector investment panics, and corporate scandals.

60. De Soto, The Mystery, supra note 58, 58-61; De Soto, The Other PATh, supra note 58 , at $250-51$.

61. Under the Marshall Plan, from 1947 to 1951 the United States gave (as grants, not loans) nearly $\$ 13$ billion to West European countries, including its former enemies. The $\$ 13$ billion given away by the United States in Marshall Plan aid was estimated to be about $\$ 88$ billion in today's terms. Curt Tarnoff, The Marshall Plan: Design, Accomplishments, and Relevance to the Present, in The Marshall Plan from Those Who Made It SuCCEED 349, 349-50, 379 (Constantine C. Menges ed., 1999). Others have estimated that the size of the Marshall Plan would be much higher, more than $\$ 100$ billion, in today's dollars. Paul Davidson, Reforming the World's Money, 15 J. Post KEYNESIAN ECON. 153, 156 (1992-93). The impact of the Marshall Plan was immediate, as economic growth increased by nearly forty percent in countries receiving the aid. Canova, supra note 29, at 1638-39.

62. Kofi A. Annan, Trade and Aid in a Changed World, N.Y. TIMES, Mar. 19, 2002, at A23 (calling for increased foreign assistance to address the crisis of global poverty); David W. Jones \& Christine Dolan, Kenyan President Envisions a "Marshall Plan" for Africa, WASH. TIMES, Feb. 20, 2000, at C1 (calling for a Marshall Plan for Africa); Robert Malley, Rebuilding a Damaged Palestine, N.Y. TIMES, May 7, 2002, at A31 (calling for foreign assistance as the cornerstone of a Mideast peace); M. Ishaq Nadiri, Rebuilding a Ravaged Land, N.Y. TIMES, Nov. 26, 2001, at A17 (calling for foreign assistance for Afghanistan's reconstruction); Richard Sokolsky \& Joseph McMillan, Foreign Aid in Our Own Defense, N.Y. TIMES, Feb. 12, 2002, at A23 (calling for a new Marshall Plan "to make terrorism wither").

63. Public sector investment and foreign assistance should also be directed to creating and improving the legal infrastructure of developing countries, including making the rule of law and legal protections for private property and contract more widely accessible. DE SOTO, THE MYSTERY, supra note 58, at 49-51 (arguing that legal protections for private property and contract are two often overlooked prerequisites for capital and market economy development); DE SOTO, THE OTHER PATH, supra note 58, at $177-82,250-51$. 
The socioeconomic approach also permits a realistic critique of other aspects of today's unregulated, corporate globalization. For instance, the liberalization of investment rules in host countries, along with lower labor and environmental protections standards, has provided powerful incentives for multinationals to engage in foreign production through foreign direct investment. But without a brake, such as minimum enforceable international labor and environmental standards, foreign direct investment could become a classic race to the bottom ${ }^{64}$ whereby large multinational corporations seek the lowest labor and regulatory costs, thereby undermining the previous comparative advantages of countries with higher wage rates and better environmental protection. ${ }^{65}$ The loss of many thousands of Mexican maquiladora jobs to Southeast Asia in only the past three years demonstrates that it is a big world, and there is always someplace lower in the race to the bottom. ${ }^{66}$ Socioeconomics points the way to reforming multilateral institutions, including the WTO, to harmonize labor and environmental standards on a regional or even global basis. ${ }^{67}$

64. John Coffee suggests that " $[\mathrm{t}]$ he term 'regulatory arbitrage' is a more neutral term for what others call the 'race to the bottom,' that is, the migration of legal entities to the more lenient regulatory regime, with consequent pressure for regulatory relaxation on all regulators." John C. Coffee, Jr., The Future as History: The Prospects for Global Convergence in Corporate Governance and Its Implications, 93 Nw. U. L. REV. 641, 650 n.31 (1999).

65. In a recent report on NAFTA sponsored by the Carnegie Foundation for International Peace, the authors conclude that the fear of a race to the bottom in environmental regulation "has proved unfounded." John J. Audley, Introduction to NAFTA's PROMISE AND REALITY: LESSONS FROM MEXICO FOR THE HEMISPHERE, supra note 39 , at 5,7 . Still, the report finds that environmental regulations were weakened in all three NAFTA countries, real spending on Mexico's pollution monitoring and on-site inspections fell by forty-five percent since enactment of NAFTA, and NAFTA has contributed to an increase in annual gross emissions of carbon monoxide and sulfur dioxide, as well as air pollution spikes in the Canadian-U.S. and U.S.-Mexican border regions. Scott Vaughan, The Greenest Trade Agreement Ever?: Measuring the Environmental Impacts of Agricultural Liberalization, in NAFTA's PROMISE AND REALITY: LESSONS FROM MEXICO FOR THE HEMISPHERE, supra note 39, at 61, 66-67. The report also finds that NAFTA has coincided with weak labor laws and falling real wages for most Mexicans and greater income inequality in both Mexico and the United States. The report further attributes to NAFTA a portion of the observed growth in U.S. wage inequality. Id. at 12-13, 24-35.

66. Juan Forero, As China Gallops, Mexico Sees Factory Jobs Slip Away, N.Y. TiMES, Sept. 3, 2003, at A3 (reporting that according to the Mexican government, 500 of Mexico's 3700 maquiladora factories have shut down since 2001, at a cost of 218,000 jobs); Elisabeth Malkin, Manufacturing Jobs Are Exiting Mexico, N.Y. TIMES, Nov. 5, 2002 , at W1 (reporting that Mexico's maquiladora industry lost 287,000 jobs between October 2000 and March 2002, a twenty-one percent decline, and that thousands of those jobs moved to China, Thailand, and Vietnam).

67. See Canova, supra note 55, at 1318 (calling for a "grand bargain" whereby developing countries would accept enforceable labor and environmental standards through the WTO, and in return, wealthy countries would accept their share of "adjustment burdens" by significantly increasing foreign aid and public capital flows to 
The law and economics approach raised the visibility of the business law curriculum in legal education. But its narrow focus on efficiency and aggregate growth failed to explain the weaknesses of the orthodox free market model. In contrast, law and socioeconomics should enrich legal education by offering more compelling descriptions of market realities while also providing the opening for richer and wider discussions about alternative reform possibilities.

\section{APPLIED INTERNATIONAL AND SOCIOECONOMIC CONCEPTS}

Although we are familiar with some use of international materials in our domestic courses, these materials tend to be limited in amount and more comparative than purely international in nature. As noted above, discussions of labor law and capital transfers can be used to compare European Union and North American approaches. Often, however, international and comparative materials are kept carefully segregated in "appropriate" courses. Our corporations courses consider homegrown incorporated business entities and focus on state corporate laws and federal securities laws and regulations. A study of non-U.S. business forms and the regulation to which they are subject awaits a course such as international business transactions. Indeed, under this segregation paradigm, even a discussion of transborder migrations is relegated to a course explicitly on "international" law or, yet more narrowly, to a course on immigration law.

The previous discussions underscore how porous are national borders, and thus how artificial is also the domestic- versus foreign-course boundary. As the description of labor law and financing in the global markets proves, this segregation has become unrealistic, and even the diffidently comparative approach is insufficient. The related point is that as

help finance the higher regulatory standards). Monetary integration in Western Europe was preceded by significant transfers of capital in the form of the European Union (EU) regional aid program by which some \$227 billion will subsidize the EU's poorer regions over the present five-year period, a veritable ongoing Marshall Plan within the EU. Drowning in a Sea of Structural Funds?, ECONOMIST, Mar. 29, 2003, at 50; see also The EU's Regional Aid: What's Ours Is Ours, ECONOMIST, May 26, 2001, at 47 (reporting that the regional assistance program makes up around thirty-five percent of the EU budget). It is telling that neither NAFTA nor the proposed Free Trade Area of the Americas proposal include any similar plans for regional aid transfers to assist poorer countries and regions to meet minimum regulatory and living standards. Timothy A. Canova, Free-Market Policies Must Help Latin America, Miami Herald, Nov. 17, 2003, at $23 \mathrm{~A}$. 
our discussions in class become more complex, the socioeconomic perspective becomes still more appropriate. How can we discuss NorthSouth labor migrations without considering the cultural and social realities, as well as economic realities, in both parts of the world? How can we even begin to discuss the appropriateness of minimum labor standards - without yet considering what they should be-before completing a careful comparison not only of the various jurisdictions' formal labor laws, but also of those laws' outcomes in context? Similarly, we cannot meaningfully analyze the desirability of a social clause in the WTO Agreement unless we include social and cultural as well as economic consequences. Any discussion of whether labor rights should be linked to intellectual property rights should consider the effect of applicable laws in their actual context. In the same way, a review of the effects of foreign direct investment and portfolio capital investment requires an appreciation of all aspects of encouraging or discouraging capital flows.

Including the international in traditionally domestic courses recognizes the reality of globalization. The socioeconomic perspective allows us to teach this complex reality in the richest, most complete way possible. It is about teaching law in context. 